(C) 1985 ISIJ

\title{
フィルターによる介在物の付着分離効果
}

\author{
市橋 弘行* ${ }^{*}$ 川島 康弘 ${ }^{*} \cdot$ 池田 隆果 ${ }^{* 2}$
}

\section{Decreasing of Inclusions by Adhesion Separation with Filter}

Hiroyuki Ichinashi, Yasuhiro Kawashima and Takami Ikeda

\begin{abstract}
Synopsis :
To separate inclusions from molten steel, a new method by filtration which is different from conventional ones based on floating-out of inclusions was investigated. Since filters with pores smaller than the diameter of inclusion are considered not to be applicable to molten steel, ceramic filters with many small holes were used with expectation of getting inclusions adhered on them.

As the first step the influences of filter shape design and deoxidation of steel on the filtration of inclusions were investigated.

Results obtained are summarized as follows :

(1) The inclusions filtered are only of alumina type and therefore this filter is effective for removal of inclusion in aluminum killed steel.

(2) Inclusions adhere at first on the edge of a filter pore where the flow of molten steel changes and grow to cover on the top surface of the filter and fill up the inner part of the pore. When the layer of adhered inclusions on the filter becomes thick, the molten steel can not go through the filter.

(3) From the reason mention above, the increase of thickness of the filter dose not improve removal of inclusions.
\end{abstract}

\section{1. 緒}

言

鋼中非金属介在物のらち, 非延性の酸化物系介在物に ついは鋼を薄鋼板や極細線に加工する際に材料断面積 に占める介在物粒径の割合が相対的に大きくなり介在物 が表面疵や断線などの各種の欠陷の原因となることがあ る. 特に深絞り用の冷延鋼板やぶりき用のDI 缶では微 細な酸化物系介在物が深絞り加工時の表面疵, あるいは 割れの原因となる1). また，タイヤ用スチールコードで は冷間線引時に介在物を起因として断線する ${ }^{2)}$. これら の介在物の減少除去方法として, 取鍋内のガスバブリン グをはじめとする取鍋精錬技術の利用と連続鋳造におい て各種対策がこれまで実施されている，例えば，取鍋一 タンディッシュ間のシール3), タンディッシュの大容量 化4), タンディッシュ内の堰の設置, タンディッシュ上. ノズルからの Ar ガスの吹き込み, タンディッシュ浸漬 ノズルの形状変更等5) 7)が採用されている.これらの対 策はそのほとんどがメタルと介在物の比重の差を利用し た介在物の浮上分離を目的としている. 介在物の浮上に は当然のことながら, 介在物が大きい方が有利であり, 徽細な介在物は衝突による凝集肥大化も浮上分離もむず
かしい.

…万方, 浮上分離とは全く異なる機構の介在物の吸着除 去を目的としたフィルターの採用がアルミニウム精鍊で 古くから行われており ${ }^{8)}$, 特にアルミ箔の製造には不可 欠とされている昂。 アルミニウム精錬で使用されるフィ ルターは数 $\mathrm{mm}$ 前後のアルミナ粒を積み重水たもの が主体であり,この時の介在物の除去機構については APELIAN ら ${ }^{10)}$ が詳述している. フィルターによる除去 方法をアルミニウムより更に高温の溶湯に採用しようと いう動きが近年活発化している． $\mathrm{Ni}$ 基合金への適用に ついて米国で格子状のフィルターが開発されており, また, 上述の APELIAN らはアルミニウムでの研究の延 長線上として，この種のフィルターを鋼に適用した研究 を行つている11)。同じく $\mathrm{Ni}$ 基合金については SUTTON 12)がフィルターの使用を記述している．著者らは鋼への 適用の第一歩として，小径多孔の耐火物フィルターを用 い, 介在物付着分離の効果を調べた。

\section{2. 実 験内容}

\section{$2 \cdot 1$ 実験方法}

実験には $200 \mathrm{~kg}$ の高周波大気溶解炉を用い, Fig. 1

昭和 58 年 4 月本会講演大会にて発表 昭和 58 年 10 月 14 日受付 (Received Oct. 14，1983)

* 住友金属工業(株) 中央技術研究所 (Central Research Laboratories, Sumitomo Metal Industries, Ltd., 1-3 Nishinagasuhondori Amagasaki 660)

*2 住友金属工業(株)中央技術研究所工博 (Central Research Laboratories, Sumitomo Metal Industries, Ltd.) 

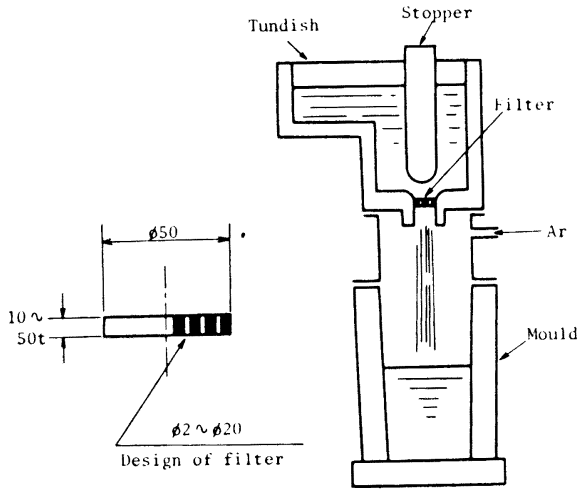

Fig. 1. Testing procedure.

Table 1. Experimental condition.

\begin{tabular}{l|l}
\hline \multicolumn{1}{c|}{ Steel } & $\mathrm{Al}, \mathrm{Si}-\mathrm{Al}, \mathrm{Si}, \mathrm{Al}-\mathrm{Ca}$ killed steel \\
\hline Material of filter & Alumina ceramics $\left(\mathrm{Al}_{2} \mathrm{O}_{3}>99.5 \%\right)$ \\
\hline $\begin{array}{l}\text { Pore diameter in filter } \\
(\mathrm{mm})\end{array}$ & $2,3,4,5,7,9,14,20,40$ \\
\hline $\begin{array}{l}\text { Thickness of filter } \\
(\mathrm{mm})\end{array}$ & $10,20,30,40,50$ \\
\hline $\begin{array}{l}\text { Velocity of molten metal } \\
\text { through filter }(\mathrm{cm} / \mathrm{s})\end{array}$ & $18,21,33,59$ \\
\hline
\end{tabular}

Table 2. Chemical composition of materials $(\%)$.

\begin{tabular}{cccccccc}
\hline Steel & $\mathrm{C}$ & $\mathrm{Si}$ & $\mathrm{Mn}$ & $\mathrm{P}$ & $\mathrm{S}$ & sol. Al & $\mathrm{Ca}$ \\
\hline Si-Al killed & 0.15 & 0.25 & 1.00 & 0.015 & 0.015 & 0.030 & - \\
\hline Al killed & 0.04 & 0.001 & 1.17 & 0.011 & 0.007 & 0.060 & - \\
\hline Al-Ca killed & 0.15 & 0.25 & 1.00 & 0.015 & 0.015 & 0.003 & 0.030 \\
\hline Si killed & 0.14 & 0.30 & 1.00 & 0.015 & 0.015 & - & - \\
\hline
\end{tabular}

に六すう法でテストした。 介在物よりも小さい孔のフィ ルターを溶鋼に適用するのは困難と思われるので付着分 離を主体において $2 \mathrm{~mm} \oint \sim 20 \mathrm{~mm} \oint$ の小径多孔を有す る円板状の耐火物を用いた。酎火物材質としては強度, 耐火度を考慮して $\mathrm{Al}_{2} \mathrm{O}_{3}>99.5 \%$, 比重 3.92 といら緻 密なアルミナセラミックスを選んだ。上ノズルにはスト ッパーを取り付け，溶鋼へッドを一定としてから鋳込み を開始する。鋳込みスタート後にはストッパーの開度を 調整せず，溶鋼へッドが一定となるように溶解炉からの 注入量を調整した.タンディッシュと鋳型の間は $\mathrm{Ar} カ ゙$ 又雾用気となつており鋳込又流の酸化は防止されてい る. 実験条件および，対象鋼種をそれぞれ，Table 1, 2 に示す。フィルターの介在物除去能力におよぼす脱酸方 法, フィルター孔径および厚さ, フィルター通過流速の 影響を調べた。フィルター通過時の流速を変える実験で
はフィルター孔径 $3 \mathrm{~mm} \phi$, 厚さ $10 \mathrm{~mm}$ の同一形状のフ イルターを用い，溶鋼へッドを変えることは実験ト:をず かしいので,フィルター直下のノズル往を絞ることで対 処した。流速は通過溶鋼量を通過時間とフィルタ一孔統 面積で割つたテントヒートの均流速でふしている。

タンディッシュにフィルターを取り付けた後，1100〜 $1200^{\circ} \mathrm{C}$ にタンディッシュを予熱し，脱酸を終厂した溶 鋼を注人する．タンディッシュ从の溶鋼温度は 1600 土 $10^{\circ} \mathrm{C}$ に調整した。 なお，フィルター一の介在物の付着 状沇を調べるために一部の実験ではストッバーを用いて 強制的にフィルター八の溶鋼の流入を中怩させ、そのま ま凝沽させた。

\section{$2 \cdot 2$ 調查方法}

フィルターの効果を調ベるためにフィルター通過前後 の Total O, 介在物の变化および鋳込み後のフィルタ 一部のミクロ調植を行つた. Total O と介在物のミクロ 調查はタンディッシュ内溶鋼より採取したサンプルと鋼 塊内で介在物浮与:の機会の最も少ない表皮から以り出し たサンプルを比較して行つた。 介在物に罜してはミクロ 観察以外にタンディッシュ队残溶鋼と鋼塊より採取した $15 \mathrm{~mm} \oint \times 150 \mathrm{~mm} L$ の試片からスライム法 $(13 \mathrm{wt} \%$ 塩 化第一鉄水溶液, $6 \mathrm{~A}$ 定電流溶解) に上り介在物を抽出 し，実体顕微鏡により形態の観察と個数の測定を行つ た.

\section{3. 調 查 結 果}

\section{$3 \cdot 1$ ブランクテスト}

Fig. 1 の実験j法ではタンディッシュ内および鋳型 内で介在物が浮上等により日然に減少することが懸念さ れる.この点を検討するため,フィルターをセットせず にトノズルのままで鋳込み、Total Oの変化を調べた。 対象鋼種は $\mathrm{Si}-\mathrm{Al}$ キルド鋼である. 結果を脱酸の影響 を調べた Fig. 2 中に併䛉する.フィルターを使用しな い場合でもタンディッシュから鋼塊にかけて Total O は減少しており，しかもその值はフィルタ一通過前の Total O 值が高いほど大きい.フィルターによる介在 物の除去能力を評価する場合，このブランク値で補正す る必要がある，従つて，Total O の減少率を求める場合 はタンディッシュ内の Total O 值からブランク值を除 いた值を基にして次式で計算した.

$$
\begin{aligned}
& \text { 酸素減少率 }=\frac{\left(\mathrm{O}_{\mathrm{i}}-\mathrm{O}_{\mathrm{b}}\right)-\mathrm{O}_{\mathrm{f}}}{\left(\mathrm{O}_{\mathrm{i}}-\mathrm{O}_{\mathrm{b}}\right)} \times(100 \%) \\
& \mathrm{O}_{\mathrm{i}}: \text { フィルター通過前の Total } \mathrm{O} \\
& \mathrm{O}_{\mathrm{b}}: \text { ブランクの Total } \mathrm{O} \\
& \mathrm{O}_{\mathrm{f}}: \text { フィルター通過後の Total } \mathrm{O}
\end{aligned}
$$




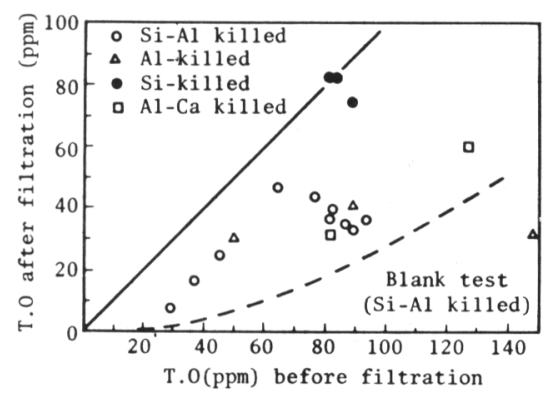

Fig. 2. Effect of filtration for each kind of steel.

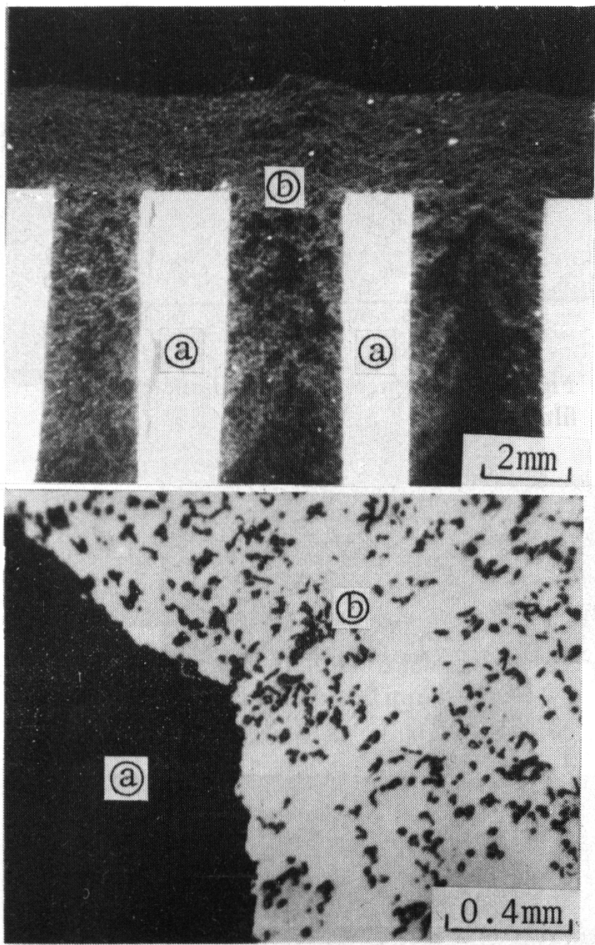

(a) Filter, (b) Alumina cluster

Photo. 1. Microstructure of the filter after filtration. (Si-Al killed steel)

\section{$3 \cdot 2$ フィルターの効果}

$3 \cdot 2 \cdot 1$ フィルター効果に拈よぽす鋼種の影響

$2 \mathrm{~mm} \oint \sim 5 \mathrm{~mm} \oint$ の径のフィルターを用い, $\mathrm{Si}$ キル ド, $\mathrm{Si}-\mathrm{Al}$ キルド, $\mathrm{Al}$ キルド拈よび $\mathrm{Al}-\mathrm{Ca}$ キルド鋼 を対象にしてフィルター効果を調べた. 結果を Fig. 2 に示す. $\mathrm{Si}$ キルド鋼ではフィルター詰まりは生ぜず, タンディッシュに注入した溶鋼がすべてフィルターを通 過するが，通過前後での Total O の減少は見られない。 他の 3 鋼種ではフィルター通過後に Total O はほぼ半
減している．ただし，図中のデータはブランク值の補正 がなされていない. Total O の減少率としては 30～60 \% 程度であり, またフィルター孔径の小さい場合には フィルター詰まりが生じ, 必ずしも溶鋼全量がフィルタ 一を通過していない。フィルターでの介在物除去状況を 確認するため，溶鋼が充填されているフィルター部を切 り出して調べた. Photo. 1 に示すよらにフィルターの 孔壁および, 上面には介在物が堆積してお抒り, 溶鋼の通 過を妨げている。堆積介在物は EPMA によればアルミ ナであり，10\% 硝酸ーアルコールで強腐食したところア ルミナクラスターがからみあつて成長していた (Photo. 5)。フィルターによつて Total O が半減している 3 鋼 種を対象にフィルター通過前後の介在物の変化を清浄度 測定とスライム法で調べた。 スライム法で抽出した代表 的な介在物の写真を Photo. 2 に, また, これらの介在 物の個数の变化と清浄度測定結果を Table 3 に示す. フィルター通過後にはアルミナクラスターが 1/10１/ 100 と大幅に減少して拈り, Total O の減少の主体がア ルミナの除去にあることがわかる。ただし，一部のヒー トでは塊状, 球状の介在物が増加した結果となつている が，これは Photo. 2 に示されるようにフィルター通過 前にはアルミナクラスターが多数存在するのでその他の

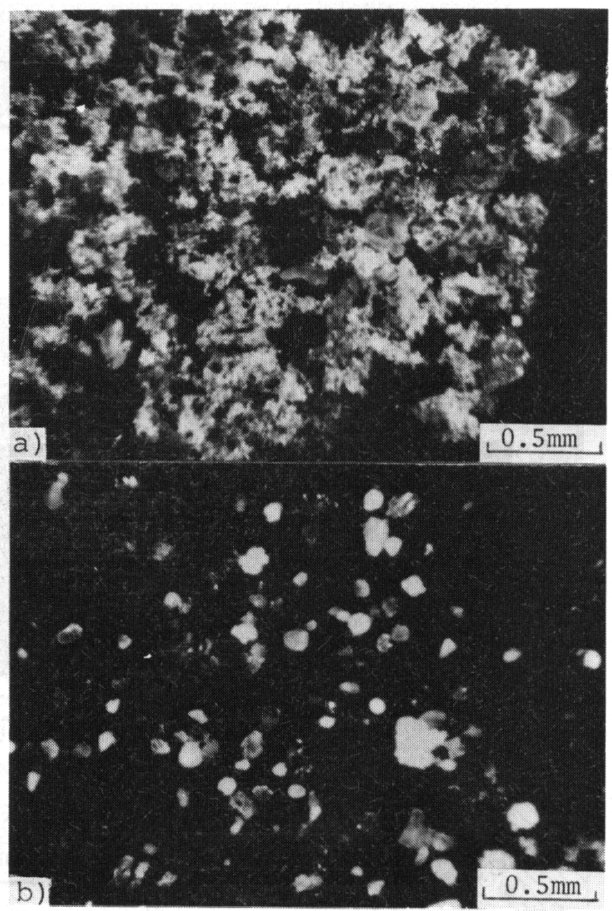

a) Before filtration, b) After filtration

Photo. 2. Morphology of inclusions extracted by the slime method. (Si-Al killed steel) 
Table 3. Results of filtration.

\begin{tabular}{|c|c|c|c|c|c|c|}
\hline \multirow{2}{*}{ Steel type } & \multirow{2}{*}{ Total O (ppm) } & \multirow{2}{*}{ Cleanness $(\%)$} & \multicolumn{4}{|c|}{ Number of inclusions extracted by slime method $(/ 10 \mathrm{~kg})$} \\
\hline & & & Alumina cluster & Lump & Globule & Total number \\
\hline \multirow{2}{*}{$\mathrm{Si}-\mathrm{Al}$ killed } & 80 & 0.079 & 111000 & 2900 & 0 & 113900 \\
\hline & 40 & 0.054 & 770 & 2362 & 64 & 3196 \\
\hline \multirow{2}{*}{ Al killed } & 59 & 0.058 & 24440 & 50 & 0 & 24490 \\
\hline & 30 & 0.042 & 94 & 785 & 356 & 1236 \\
\hline \multirow{2}{*}{ Al-Ca killed } & 81 & 0.042 & 10489 & 43 & 43 & 10574 \\
\hline & 32 & 0.021 & 1604 & 229 & 104 & 1937 \\
\hline
\end{tabular}

\section{Before filtration}

After filtration

介在物を正確に測定することがむずかしく, 測定誤差と も考光られる.

\section{$3 \cdot 2 \cdot 2$ フィルター形状および流速の影響}

Si-Al キルド鋼を対象に介在物除去率におよぼすフィ ルター形状, 流速の影響を孔径, 厚さ, 流速を变えて調 べた. $\mathrm{Si}-\mathrm{Al}$ キルド鋼を選んだ理由は小型溶解炉では低 炭 $\mathrm{Al}$ フルキルド鋼の成分調整がもずかしいことと，著 者らの実験結果ではフィルター効果に対して $\mathrm{Al}$ キルド 鋼と汪とんど差がなかつたためである.

フィルター孔径を $2 \mathrm{~mm}$ から $20 \mathrm{~mm}$ まで変化させた が, できる限り流速を一定とするため孔総面積が一定と

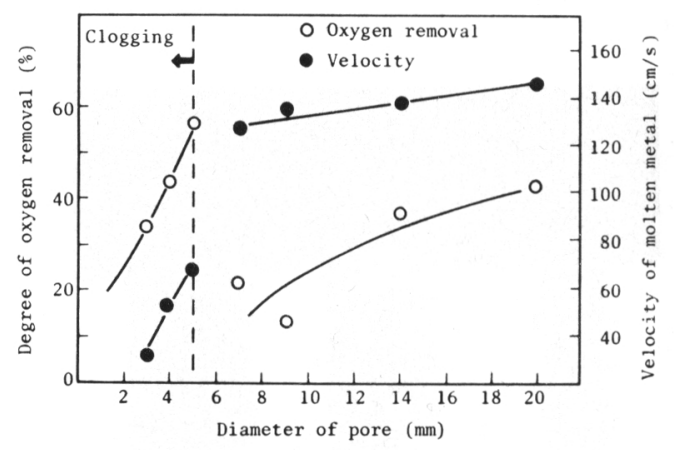

Fig. 3. Influence of pore diameter and filtration.
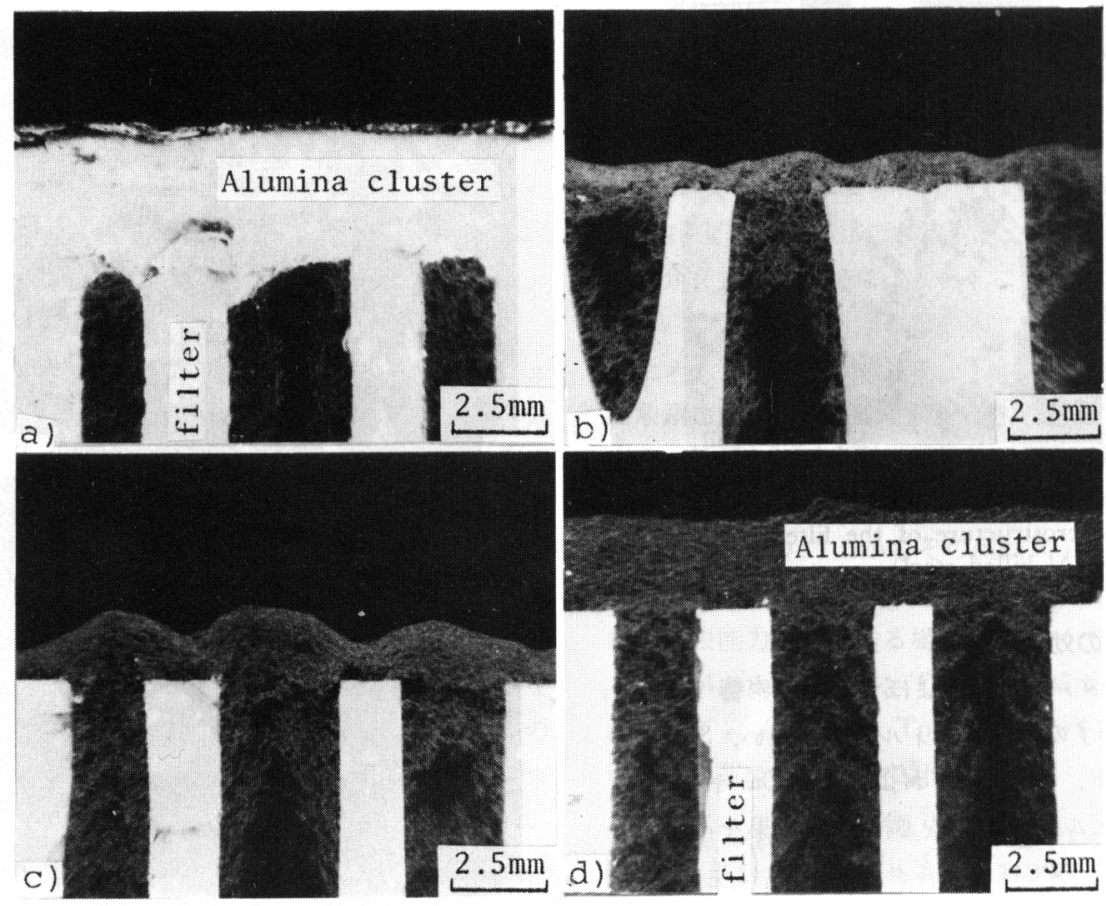

a) $18 \mathrm{~cm} / \mathrm{s} 76 \%$

b) $21 \mathrm{~cm} / \mathrm{s} 48 \%$

c) $33 \mathrm{~cm} / \mathrm{s} 21 \%$,

d) $59 \mathrm{~cm} / \mathrm{s} 60 \%$

Photo. 3. Influence of velocity of molten metal on the filtration. 
なるよらに孔個数を選んだ. 結果をFig. 3 に示す. 図 中には参考のため平均流速の值も併記している. $2 \mathrm{~mm} \oint$ では鋳込不可能であり, $5 \mathrm{~mm} \oint$ 以下ではフィルター詰 まりが発生している。フィルター詰まりした方が除去率 は高いが,フィルター孔上を覆らアルミナの成長のため か, 詰まりのないヒートに比べ著しく流速が低下してい， る、フィルター詰まりのある場合もない場合もそのおの おのの範囲では孔径の大きい方が流速が大きく, 除去率 も高くなる傾向にある，次にフィルター通過流速を変光 る実験を行つた．孔径 $3 \mathrm{~mm} \oint$, 厚さ $10 \mathrm{~mm}$ のフィルタ 一をセットし,フィルターの直下のノズル往を12 mm まで絞つて流速を変光た。結果を Photo. 3 に示す.実

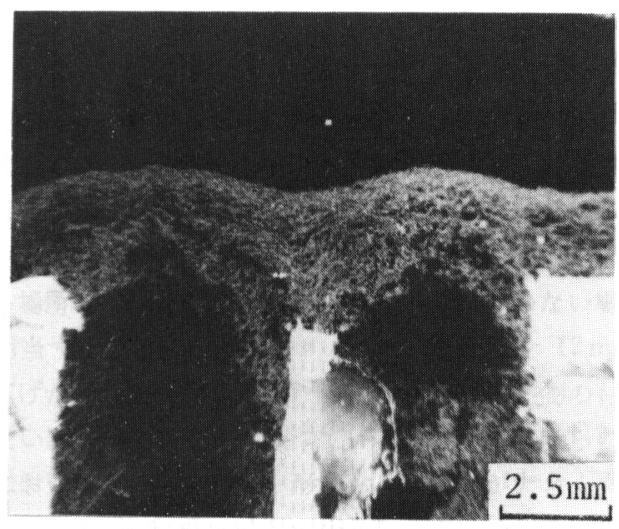

Photo. 4. Influence of filter thickness on the filtration. (Filter thickness $30 \mathrm{~mm}$ )
験はいずれもフィルター詰まりを生じており，流速は通 過溶鋼体積を通過時間とフィルター孔総面積で割つた值 で示している.アルミナの付着形態の異なる流速 $18 \mathrm{~cm}$ / s 以外は流速の増加により介在物除去率は増大して打 りまたフィルター上面のクラスター厚さも厚くなつて いる.

一方, 介在物除去率に占めるフィルター孔壁の役割を 明らかにするためにフィルター厚さを $10 \mathrm{~mm}$ から 50 $\mathrm{mm}$ まで変化させた. 結果はフィルタ一厚さを厚くする ほど通過溶鋼量が少なく, フィルターへのアルミナの付 着がフィルタ一上面でのみ生じ, 孔内部の厚さ方向には あまり見られなかつた (Photo. 4)。従つて Total O の 減少量も少なく, 厚みを厚くした効果は全くなからた。

\section{3 フィルター部のミクロ調査}

フィルターへの介在物の付着機構を明らかにするため に実験後の介在物が付着したフィルターを調べた。付着 形態を分類するとPhoto. 5 のごとく次の 3 種類となる.

（a）アルミナクラスターが集積し, 隆起状に付着し ている.

Table 4. Chemical composition of adherent material to filter by EPMA.

\begin{tabular}{c|c}
\hline \multicolumn{1}{c|}{ Steel } & Chemical composition \\
\hline $\mathrm{Si}-\mathrm{Al}$ killed & $\mathrm{Al}-\mathrm{Mn}-(\mathrm{Si})-(\mathrm{Ca})-\mathrm{O}, \mathrm{Fe}-\mathrm{O}$ \\
\hline Al killed & $\mathrm{A} l-\mathrm{Fe}-(\mathrm{Ca})-(\mathrm{Mn})-\mathrm{O}$ \\
\hline $\mathrm{Al}-\mathrm{Ca}$ killed & $\mathrm{Al}-\mathrm{Si}-\mathrm{Mn}-\mathrm{Ca}-\mathrm{O}, \mathrm{Al}-\mathrm{Mn}-(\mathrm{Si})-(\mathrm{Ca})-\mathrm{O}, \mathrm{Fe}-\mathrm{O}$ \\
\hline
\end{tabular}

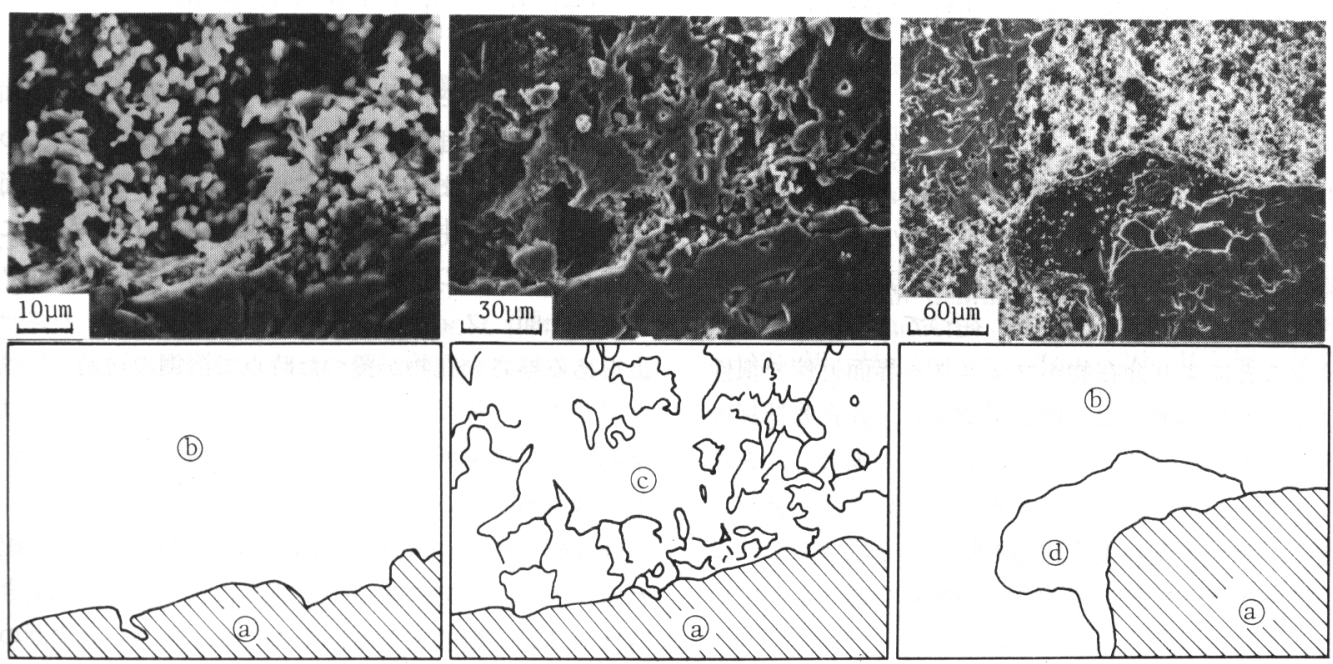

(a) Filter, (b) Alumina cluster, (c) Fused alumina cluster, (d) Adherent material Photo. 5. SEM observations of inclusion adherent to filter. 


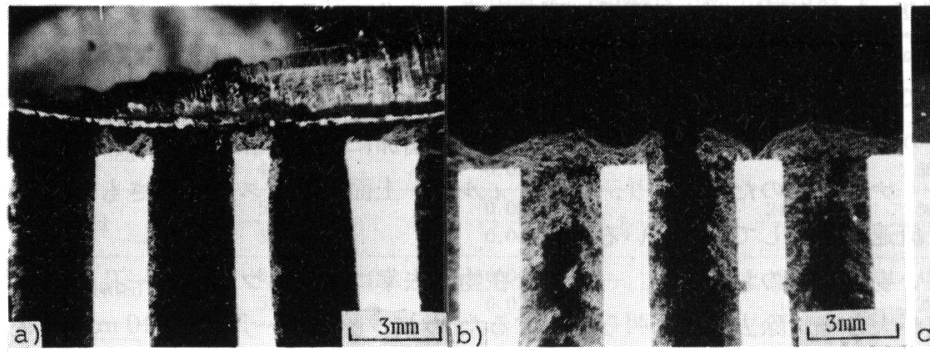

a) After $10 \mathrm{~s}$

Photo. 6. Growth of inclusion adherent to filter during filtration

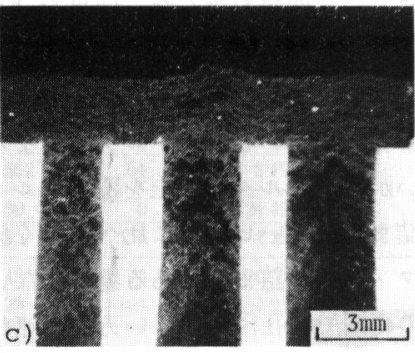

c) After $30 \mathrm{~s}$ （b） 半溶融状のアルミナクラスターが付着してい る.

(c) 溶融物がフィルターに付着し, それらにアルミ ナクラスターが更に付着している.

次に介在物付着部の組成を調査するため付着界面の組 成を EPMA で同定した.フィルターとメタルは鋳込完 了後にはメタルの収縮で分離しやすく, 付着界面を決定 することはもずかしいが調査界面にはアルミナ以外に一 部 Table 4 に示すように Al-Mn-O が検出されてい る。

一方, 付着介在物の成長状況を調べるため Si-Al キルド鋼を $3 \mathrm{~mm} \oint$ 孔のフィルターに鋳込んでいる途 中でストッパーを閉じ，フィルター部にメタルを残存さ せた。実験は 3 ヒート行い, 鋳込開始後, おの沶の 10 , $20,30 \mathrm{~s}$ で鋳込みを中止した. このフィルター部のミク ロ写真が Photo. 6 である. アルミナクラスターがフィ ルター上面の孔コーナー近傍からしだいに成長し，フィ ルター上面と孔壁部を覆ら状況が明瞭に観察される.

\section{4. 検討}

粒状介在物のベッドからなるフィルターを用いた APELIAN らは10111) 介在物の除去機構として, $30 \mu \mathrm{m}$ 以 上の介在物は通過を阻止され, それより小さな介在物は 耐火物の界面に拡散, 衝突, 重力ないし表面張力により 捕捉されることを提案している. 従つて, 溶湯流速を増 加させることにより介在物がフィルター界面近傍で慣性 力により流れから飛び出す機会が増加し, 介在物捕捉能 力が増大すると述べている. ただし, この場合, 介在物 がフィルターベッド内に滞留する時間が短くなり捕捉さ れる機会が減少するので介在物の除去率を増すためには フィルターベッドを長くすることが必要であるとしてい る.

一方, APELIAN らの実験条件とはフィルター形状が 大きく異なり, 流速が一桁以上も大きい著者らの実験で

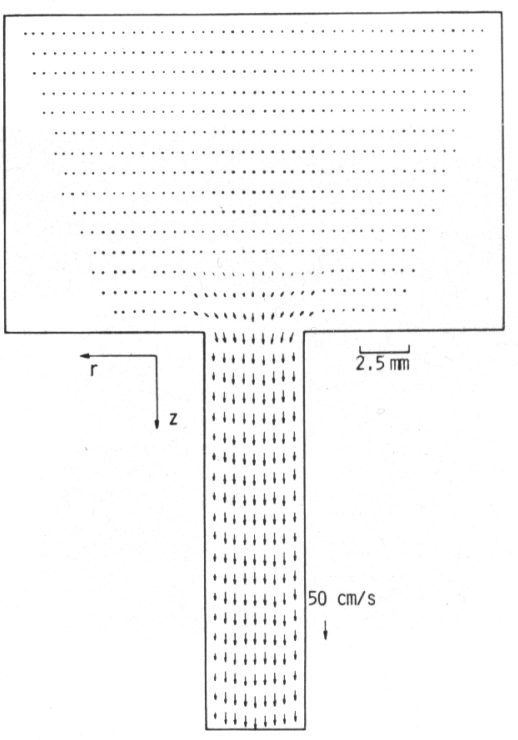

Fig. 4. Computed velocity profiles. (Arrows denote direction of velocity vector.)

はフィルター厚さを厚くしても介在物の除去率は増加し ていない.この理由はフィルター孔壁の厚さ方向への介 在物の付着があまり見られず，付着がフィルター上面お よび孔上部に集中 していたためである. Photo. 6 に示 すよらに介在物の付着は孔コーナー部から始まり, フィ ルター上面, フィルター孔内へ成長するがフィルター孔 上をある厚さ介在物が覆つた時点で溶鋼の通過が妨げら れてしまう。従つて,フィルター詰まりした央験では結 果的には付着場所が充填されるまでの挙動を調べている

\section{ことになる。}

介在物の動きは溶鋼中では浮力と溶鋼の流速に支配さ れるが流速が浮力による上昇速度に比べて極端に大きい 時は流速が支配的となる，そこでフィルター孔周囲の流 速分布を推定してみる. 計算を簡単にするため Fig. 4 に示すよらにフィルター孔は 1 コとして円筒座標とし 


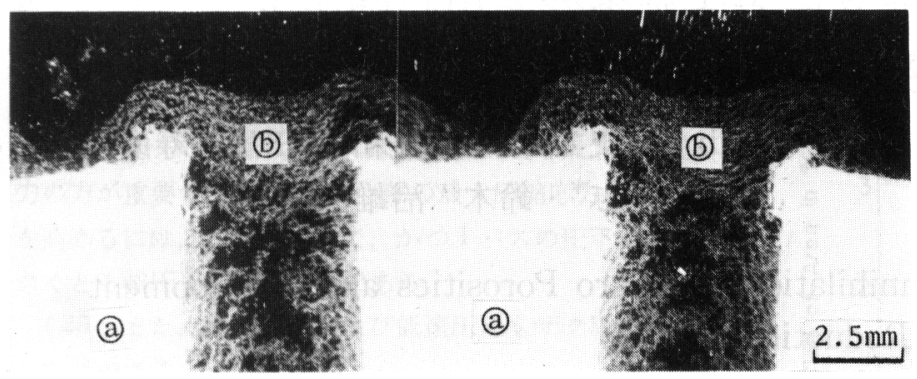

(a) Filter, (b) Alumina cluster Photo. 7. Adherent condition of inclusion to filter. ( $\mathrm{Si}-\mathrm{Al}$ killed, Mulite filter, pore dia. $=5 \mathrm{~mm} \oint, \quad$ pitch $=12$ $\mathrm{mm}$ )

た、基本方程式は連続の式と運動方程式であり，簡単の ため層流の場合について解いた ${ }^{13)}{ }^{14)}$. フィルター内の平 均通過流速を実験結果より仮定し，これに見合う一様な 流速分布を Fig. 4 の上端で与えて境界条件とした。 た，管壁では流速を零とした。ただし，実験範囲でのレ イノルズ数は 2000〜30000 であつた. 計算結果をFig. 4 に示す. 管壁コーナー部の滞留域の存在と孔コーナー 部の流れの变化, 流速の急激な上昇が観察される.この 流れの変化する場所が Photo. 6 に示すように介在物の 付着が始まる場所とよく一致しており，また，Photo. 6 (b) のフィルター孔間の中央部の介在物の付着が遅れ る場所が Fig. 4 の管壁コーナー部の流れのない場所に 相当すると考兄られる. フィルター孔間隔を $12 \mathrm{~mm}$ に 広げた実験では Photo. 7 に示すよらに介在物の付着の ない部分が更に明瞭になつている. 従つて著者らの実験 に拈いても，フィルター形状および流速が大きく異なつ てはいるが APELIAN らの唱えるように流れの変化する フィルター界面に打いて流れから介在物が飛び出し，フ ィルターに付着する機構が最も支配的なものと考光られ る.

\section{5. 結言}

小径多孔の耐火物フィルターを溶鋼に適用し, 介在物 の付着分離におよぼす脱酸方法, フィルター形状の影響 を調べた。その結果, 以下に示す項目が明らかとなつた。

1) フィルターに付着する介在物はアルミナであり, 従つて, Al 脱酸した鋼の介在物低減には有効である. 特にアルミナクラスターの低減には顕著な効果が見られ た。

2) 介在物は流れの変化するフィルター孔コーナー部 から付着しはじめ, フィルター上面と孔内部を覆う形で 成長し，付着介在物層がある厚さ以上となると溶鋼がフ ィルターを通過できなくなる。
3)上述の理由から，フィルター厚さを厚くしても介 在物の除去率は向上しない.

終わりに本研究の遂行にあたり, 終始有益な御指導, 御教示を賜つた住友金属工業(株), 常務取締役, 中央技 術研究所長 西岡邦夫博士, 本社チタン事業センター長 梅田洋一氏，ならびに中央技術研究所副所長，行俊照夫 博士に厚く感謝致します.

\section{交献}

1) 松藤和雄, 下村隆良，小林英男，黒河照夫，宮原 忍：日本鋼管技報（1982） 92，p. 27

2 ）峰 公雄, 松野淳一, 角山浩三, 原田俊一, 佐藤 周三，中島 力，佐々木寿毅，片岡圆彦：川崎製 鉄技報， 11 (1979)，p. 621

3 ) 植田嗣治, 丸川雄浄，豊田 守：鉄と鋼，60 (1974), p. 943

4 ) 大西正之, 岩永侑輔, 日和佐章一, 加藤安功, 大 図秀志：鉄と鋼，69(1983)，S 211

5 ) 駒村宏一, 久々湊英雄, 小嶋英明, 越川隆雄, 上 杉浩之，児玉正範，吉井 裕，垣生泰弘，江見俗 彦: 鉄と鋼, 67 (1981), A 133

6 ) 山村 稔, 内田繁孝，田口喜代美，宮原 忍，菅 原功夫：鉄と鋼, 67 (1981), A 137

7 ) 小林隆衛, 川崎守夫, 豊田 守, 渡部忠男, 中島 敬治：鉄之鋼，67 (1981)，A 141

8 ) L. C. Blayden and $K$. J. Brondyke: Light Metals (1973), p. 493[AIME]

9 ) $R$. Mutharason, $D$. Apelian and $C$. Romanowski: J. Met., 33 (1981) 12, p. 12

$10)$ D. Apelian and R. Mutharason: J. Met., 32 (1980) 9, p. 14

11) D. Apelian: Japan-U. S. Cooperative Science Program Seminor on Solidification Processing, Massachusetts (1983)

12) $W . H$. Sutton: Proc. 7th ICVM (1982), p. 916

13) J. Szekely，浅井滋生：鉄と鋼，61（1975), p. 2012

14) A. D. Gosman, W. M. Pun, A. K. Runchal, $D$. $B$. Spalding and $M$. Wolfstein: Heat and Mass Transfer in Recirculating Flows (1969), p. 231 [Academic Press, London and New York] 